\title{
O Haiti e suas elites: o interminável diálogo de surdos*
}

\section{Haiti and its elites: the never-ending dialogue of the deaf}

Jean Casimir ${ }^{1}$

\footnotetext{
Este artigo foi elaborado a partir de uma conferencia proferida no Colegio del México, intitulada "Formação e Inserção do Haiti na Comunidade Internacional", em 27 de novembro de 2006. Publicado pela Éditions de l'Université d'État d'Haiti, em abril de 2009. Tradução para o português de Renata de Melo Rosa.

1 Jean Casimir é professor da Faculdade de Ciências Humanas da Université d'État d'Haiti, foi professor da Faculdade de Ciências Políticas e Sociais da Universidad Autónoma de México (UNAM) e, na qualidade de professor convidado, na Universidade de Stanford e na Universidade das Índias Ocidentais, campus de Saint Augustin em Trinidad Tobago e de Mona, na Jamaica.
}

\section{Resumo}

$\mathrm{O}$ artigo analisa as raízes coloniais das relações de poder vigente no Haiti a partir de uma percepção acerca da constituição das elites coloniais, dentre as quais se insere o grupo de ex-escravos libertos haitianos que reproduziam as relações de poder, de escravidão e de privilégios do sistema de plantation, inclusive a racialização das relações de trabalho. Com a rebelião de 1791, este grupo perde poder e terras e se rearticular para a retomada do controle do Estado Haitiano, o que ocorre após o assassinato de Dessalines e a consequente fragmentação do Estado haitiano. O ponto central da análise incide na ideia de que as elites que controlaram o Haiti pós-colonial construíram a necessidade da dependência estrangeira que assola o país até os dias atuais, momento em que é alvo de uma intervenção armada aprovada sob a égide do Cap. VII da Carta das Nações Unidas.

Palavras-chave: Elites haitianas. Dependência estrangeira. Racialização das relações de trabalho. Intervenção.

\begin{abstract}
This paper analyzes the roots of colonial relations in Haiti since a perception of the colonial elites, including the Haitians ex-slaves who reproduced power relations of slavery and privileges on the plantation system, based on the racialization of labor relations. With the rebellion of 1791, this group loses power and lands and rearticulates itself to retake control of the Haitian state, after the Dessalines murder and collapse of Haitian state. The focus of the analysis focuses on the idea that elites who controlled the Haiti postcolonial built the need to foreign dependency that plagues the country until today, when it is the target of an armed intervention adopted under Chapter VII of the UN Charter.
\end{abstract}

Keywords: Haitian elites. Foreign dependence. Racialization of labor relations. Intervention. 


\section{Introdução}

A reflexão sobre a história de um povo, com vistas a entender as mudanças que origina e eventualmente promove, leva em consideração as raízes da cultura desse povo. Os postulados que guiam os conquistadores ajudam a entender sua própria história e não a que, diariamente constroem os conquistados. Não existe uma via universal pela qual todos os povos tenham que percorrer e a humanidade, ontem, hoje e em toda a sua diversidade, está constantemente abrindo caminhos. Por meio deles, a atitude de superioridade tanto dos pensadores haitianos como dos estrangeiros, da maneira como produzem ciência e conhecimentos a partir do memorável encontro de dois mundos em 1492, impossibilita a apreensão do passado dos oprimidos, sem permitir a mais modesta intuição acerca do ponto de vista dos derrotados.

A historiografia tradicional registra em Hispaniola ou em Saint-Domingue a presença de índios, negros e brancos. Elabora enormes tratados sobre o comportamento desses personagens com a maior indiferença em relação à maneira como eles próprios se identificam. Se os conquistadores de outrora se comportassem de outra maneira, não teria havido conquista. Mas, contemporaneamente, dificilmente se entende que essa epistemologia continue ditando a produção de conhecimentos entre aqueles que não se propõem a conquistar novos mundos. Se sabemos que os "negros" ou os "índios" são tão humanos como os "brancos", que encontremos outra epistemologia, uma que respeite as culturas vigentes. A que frequentemente é utilizada reproduz da forma mais perniciosa o etnocídio dos séculos passados e empobrece a todos nós. É preciso dar as costas à historiografia $\mathrm{e}$ à epistemologia tradicionais e investigar países como o Haiti, a partir dos postulados dos haitianos e não com os do Ocidente cristão.

Em uma colônia de exploração, a dominação estrangeira cria o lugar da prática política. O Estado haitiano brota no campo de batalha de vários impérios coloniais, lutando para incrementar a riqueza de seus nacionais. Em Saint-Domingue, somente uma minoria - os libertos - se insurge com o objetivo de defender e melhorar sua posição social. O conflito entre essa minoria que evoluiu ao som das ideias "mundialmente" aceitas e a maioria que reclama seus direitos mais elementares surge desde o nascimento do Estado e da sociedade haitiana em 1804.
No entanto, no século XIX, os estados ocidentais encontram novas fontes de riquezas fora do Caribe e deixam de pressionar em excesso os fazeres cotidianos da região. Durante a nova partilha do mundo, a ilha e o resto do arquipélago mudam de importância econômica por um lugar na geopolítica do Ocidente. Decorre daí uma marginalização da nação haitiana que facilita a construção de suas instituições sociais com relativa independência e a estruturação de um tipo de Estado que corresponde às suas próprias características. Contudo, a partir da segunda metade do século, as pressões externas sobre a estrutura política e social do país vão aumentando, conforme se alinha ao imperialismo, até sua ocupação em 1915 pelos Estados Unidos. Essa ocupação responde à necessidade norte-americana de controlar a rota comercial de costa pacífica à atlântica. Pertence à época do Big Stick e não tem qualquer relação com a dinâmica interna da república agredida.

De 1804 até os nossos dias, as relações do Haiti com a comunidade internacional têm sido dramáticas. As que o unem com a América Latina se dão dentro de um marco inóspito. Sem dúvida, essa sub-região não tem conflitos maiores com o Haiti. No entanto, não se observa e nem se espera observar uma aproximação paulatina que acumularia resultados cumulativos consideráveis. A América Latina se concebe como um segmento específico do Ocidente. Os postulados que a guiam não são compatíveis com a negociação de um intercâmbio recíproco dentro de um marco de respeito mútuo que o povo haitiano tem direito de esperar.

\section{0 trabalhador colonial e a pérola das Antilhas}

Durante o século XVII, a presença da França em Saint-Domingue se revela com a organização de uma diminuta colônia de povoamento por protestantes huguenotes que substituem brevemente os piratas e outros marginais da época estabelecidos em sua costa norte-ocidental. No final do século XVII e no início do XVIII, a estancada colônia de povoamento retrocede em direção ao estabelecimento de plantações de gêneros tropicais, o que exigiu escravizar uma população de cativos estrangeiros ${ }^{2}$ que passam a constituir uma mão de obra descartável, renovada essencialmente mediante o tráfico de escravos.

\footnotetext{
2 A escravidão supõe uma classe servil estrangeira. Ver MEILLASOUX, 1998, p. 23 e também BENOT, 2003, p. 8.
} 
Por mais francesa que tenha sido a colônia de Saint-Domingue, ela se situa em um sistema político mais amplo que busca a força de trabalho que suas empresas necessitam, entre um conjunto de seres concebidos como selvagens ou idólatras, inferiores e sem direitos. Essa inferioridade é um descobrimento do Ocidente cristão. No Haiti, ou em qualquer outro lugar da América, o "negro" ou o "índio" são uma invenção do Ocidente. O primeiro é fabricado sistematicamente como o trabalhador colonial por excelência. ${ }^{3}$ Quem não anseia ter ou administrar uma colônia de exploração, prescinde dessa unidade de análise.

A peculiaridade da história de Saint-Domingue e do Haiti, comparada às ilhas circunvizinhas, reside no fato de que a França não tem tempo de criar o negro, o seu negro. Não possui os recursos para conseguir a crioulização dos boçais ${ }^{4}$ e muito menos para fomentar um rápido crescimento da população de cativos crioulos. Administra a colônia sem cancelar a eficácia das culturas vigentes, ou seja, a visão de mundo peculiar que caracteriza os recém-chegados. De fato, inaugura a agricultura de plantation na ilha um século após desenvolvê-la em Guadalupe e na Martinica, e depois que a Inglaterra a havia iniciado nas ilhas que ocupa. Para compensar a falta de coesão social na economia e na sociedade de Saint-Domingue, a metrópole incrementa a dose de coação extraeconômica que utiliza em sua gestão.

Dito isso, a institucionalização da distinção colonial entre "brancos", "mulatos" e "negros" estandardiza a conduta dos ocidentais e de seus discípulos ocidentalizados, mas não necessariamente a de seus subordinados. A manutenção e a difusão da cultura colonial é um requisito imprescindível para que existam o colonizador e seus associados. O oprimido, por outro lado, sonha apenas em sobreviver a todo custo e a cultura colonial escravista não é forçosamente a opção mais eficaz para alcançar essa meta.

Dois fatores que não guardam relação imediata com a economia de plantation têm um impacto significativo sobre a história que Saint-Domingue divide com as demais ilhas de plantation do Caribe. Em primeiro lugar,

3 O "branco" é a contraparte do trabalhador colonial; o "mulato" ou "mestiço" são corolários da polarização entre "brancos" e "negros".

4 Chama-se boçal o cativo nascido na África. Ignora os usos e costumes da colônia. trata-se da última economia de plantation organizada a partir do capitalismo mercantilista. Em segundo lugar, seu tamanho é maior que o das economias de plantation juntas e sua geografia acidentada dificulta a gestão da sociedade escravista implantada.

Em Saint-Domingue, a economia de plantation cria raízes sólidas na segunda década do século XVIII. A emancipação geral dos escravos data de 1793. Por conseguinte, a população trabalhadora está submetida ao regime escravista durante um lapso de tempo relativamente curto. Ademais, o contato entre os cativos e o Ocidente cristão não deixa de ser superficial, devido ao reduzido período de vida útil dos escravos, sua alta mortalidade, a ausência de núcleos familiares, o ritmo de rotação da força de trabalho e o coeficiente em constante crescimento de cativos por donos.

O grosso da população servil desembarca depois de 1740. Os ritmos de chegada alcançam os 40.000 por ano na década que antecede o ano de 1793. Contabiliza-se uma média de até vinte cativos por um branco. Ao final do período colonial, os dois terços dos cativos, aproximadamente meio milhão, nasceram fora do território colonial. Portanto, a massa de trabalhadores não se orienta exclusivamente pelos valores que sustentam o sistema produtivo e que circulam, sobretudo, entre as classes privilegiadas. A coação extraeconômica alcança então uma magnitude que impossibilita a normalização da vida privada dos escravizados. A mão de obra, sendo descartável, se multiplica predominantemente pelo tráfico negreiro. A "pérola das Antilhas" é o fruto de um nível de selvageria inaudita.

Por essa razão, àqueles que falam do Haiti como um estado falido, não se dão conta que Saint-Domingue também é uma colônia falida. A ingovernabilidade que parece caracterizar o estado haitiano é exatamente a mesma que tipifica a colônia francesa e que explica porque a metrópole a perde de forma lamentável.

Comparemos brevemente Saint-Domingue com Barbados. A ilha de Barbados tem uma superfície de 430 $\mathrm{km}^{2}$, enquanto que La Gonave ${ }^{5}$ no golfo em frente a Porto-Príncipe, tem $800 \mathrm{~km}^{2}$. Barbados não tem montanhas, enquanto que o nome Haiti significa terra montanhosa. Nesse território, desde 1700, o grosso da população cativa

\footnotetext{
5 La Gonave é uma ilha localizada a oeste de Porto Príncipe. Nota da tradutora.
} 
se reproduz in situ. Isso acontece vinte e cinco anos antes de a França iniciar investimentos de peso no sistema de plantation de Saint-Domingue. Quando a Inglaterra proíbe o tráfico negreiro, os plantadores de Barbados estimam que essa medida deveria ter sido tomada vinte anos antes, já que eles não necessitavam de mão de obra importada. ${ }^{6}$

No entanto, em Saint-Domingue, a metrópole encara uma rebelião endêmica. Em 1790, se produz uma revolução geral que leva a um dos insurgentes a se autoproclamar governador geral da ilha. Esse antigo escravo devolve à França todas as autoridades enviadas para manter a ordem, incluindo o próprio cunhado do ilustre Napoleão. Que fracasso maior pode haver? Convém aos franceses ou a seus discípulos falarem de "pérola das Antilhas", mas Saint-Domingue é um desastre de colônia. Sem dúvida, a resistência dos cativos da Barbados britânica não produz, em dois séculos e meio, tantas insurreições e mortos que a dos cativos de Saint-Domingue em um ano. Como pode então uma colônia se tornar independente por meio das armas, se não é uma colônia falida?

Quando se fala de economia de plantation e de mercado de trabalho ${ }^{7}$, postula-se a necessidade de uma forma ou outra de etnocídio, ou seja, de erradicação dos valores centrais da população cativa. A fabricação do trabalhador colonial começa com a racialização das relações de trabalho. Entretanto, é preciso construir, sobretudo, a alteridade deste e inventar uma bateria de indicadores sociais que permita identificá-lo e segregá-lo. O etnocídio é muito mais sutil que o racismo; a superioridade é levada a cabo fundamentando-se em uma suposta superioridade cultural que abarcaria não somente o acervo de informações contidas em um sistema cultural, mas também aqueles que são portadores de indícios, por mais modestos que sejam, dessa cultura.

\footnotetext{
6 "That Barbados by the 1780s no longer required substantial inputs of imported African slaves to maintain its servile labouring population was reflected in the views of some prominent planters who supported the abolition of the slave trade. For example, Robert Haynes in 1806 wrote to an absentee proprietor in England saying: 'For my part, I sincerely rejoice at the abolition of the Slave Trade [...]. I sincerely wish the trade had been totally abolished 20 years ago' " (BECKLES, 1984, p. 54).

7 Do Código Negro de Luís XIV (1685), das políticas agrárias de Toussaint Louverture, de 1801 a 1802, às de Henry Christophe de 1806 a 1820, de Boyer 1818 a 1843, e de Geffrard em 1859 a 1867 , observa-se a mesma necessidade de destruir a visão de mundo dos trabalhadores.
}

Acontece que em Saint-Domingue, a França vê negros por todos os lados, e um ou outro mulato. Acontece também que somente os franceses e seus discípulos pensam que os brancos são seres superiores. Se não fosse assim, se "negros" e "mulatos" se autoconcebessem como inferiores, por que razão a metrópole perde tantos soldados e tantos recursos para pôr ordem no território? Se os "mulatos" interiorizassem sua inferioridade, por que tanto esforço na luta para conseguir a cidadania? Por que Toussaint se rebela, se sabe que é um ser inferior nascido para obedecer? Nessa colônia em que sacode uma rebelião que dura pelo menos 14 anos - de 1790 a 1804 -, ninguém acredita na superioridade do "branco". A França jamais chega a fabricar o trabalhador colonial e a converter os cativos em "negros”, em seus "negros”. Os metropolitanos não os ignoram, já que estão sempre com as armas nas mãos.

Para que a plantation de gêneros de exportação funcione sem conflitos que não possam ser administrados, as metrópoles têm que conseguir que a mão de obra não sobreviva a não ser que trabalhe sem cessar em proveito do colonizador. Bloqueiam, na medida do possível, toda a expressão da cultura original. Buscam eliminar e descaracterizar todo o conhecimento e valores recebidos dos antepassados, assim como aqueles que a população possa formular com autonomia. O objetivo perseguido consiste em inculcar os princípios e as informações elaboradas pela metrópole e assegurar sua primazia incontestável.

Esse processo é chamado de integração, assimilação ou crioulização e se dedica a um tipo especial de escravo: o emancipado ou liberto. É comum conceber o emancipado como uma pessoa livre, incluindo seus descendentes e os descendentes de seus descendentes como sendo emancipados ou libertos. Por conseguinte, ele carrega consigo a marca do estamento servil de onde emerge sua linhagem. ${ }^{8}$ Conhecedores de ambas as caras da co-

\footnotetext{
8 Notei em outra oportunidade que a palavra escravo é um substantivo, enquanto que as palavras "emancipado ou liberto" são adjetivos que qualificam o substantivo escravo. "Les dispositions de l'article 58 concernant le respect dû par l'affranchi à son ancien maître et à ses proches doivent être lues en valeurs absolue: le Blanc est intouchable. Telle est la pratique. Tel est l'esprit de la loi. Le principe de l'irréversible infériorité sociale - et juridique - du Noir, même affranchi, est de ceux que la colonie ne discute pas”. (SALA-MOLINS, 2003, p. 213).
} 
lônia, os emancipados, tornam-se imprescindíveis como especialistas da crioulização, ou seja, do etnocídio.

Pelo fato de esse etnocídio ser indispensável, os personagens principais da economia de plantation - o senhor e o trabalhador colonial - carecem de história própria. Seus intercâmbios recíprocos não modificam sua conduta social. A história que vivenciam juntos é a do Império, não a sua. São personagens de invenção cotidiana que se adaptam sem cessar no ambiente internacional onde nascem e evoluem conforme a dinâmica desse entorno. O espaço físico ou social por onde se movem, não é mais do que um receptáculo de impactos externos e não um ambiente suscetível de ser controlado, manejado, protegido e melhorado por aqueles que o ocupam. As características específicas desses personagens, suas funções e seu porvir variam segundo as necessidades dos países hegemônicos, donos da história universal. É essa história que produz a "pérola das Antilhas" e contabiliza seus êxitos.

Diante disso, a Revolução Francesa e a Declaração dos Direitos do Homem que a acompanha se fazem presentes na colônia por intermédio dos libertos. Ao se aplicar à realidade de Saint-Domingue, seus postulados se apresentam desconectados, já que, em seus propósitos passam por alto à iniludível racialização das relações de trabalho. Os libertos se esforçam para implementá-los sem desfiar o racismo vigente. A população servil, educada em sua maioria fora da colônia, não tem dificuldade em apreciar o fundamento dos Direitos do Homem, o qual toma a Revolução Francesa de surpresa ${ }^{9}$. Produz-se, então, uma greta entre os franceses metropolitanos e os libertos que inicia a destruição da pérola das Antilhas.

\section{A superação do negro ocidental}

A historiografia, que não leva em consideração suas próprias distâncias em relação ao vocabulário e aos conceitos da época colonial, distingue o desempenho dos "antigos livres" (anciens libres) dos "novos libertos" (nouveaux libres). Os primeiros herdam sua emancipação dos parentes libertos ou a conseguem por esforço próprio ou graças a seus donos. Durante a Revolução Francesa,

\footnotetext{
9 Louis Sala-Molins (1987, p. 221 e seguintes) mostra como os escravos negros das colônias são invisíveis para os filósofos da Ilustração e de forma muito particular para Montesquieu.
}

colocam suas recriminações no seio da Convenção ${ }^{10}$, em sua qualidade de grandes proprietários de terra e de ${ }^{11}$. Os segundos, os "novos libertos", recém chegam à cidadania com a emancipação geral de 1793. A Revolução Francesa os encontra em cadeias. Em muitas oportunidades, para fazer mais gráfica a distinção entre essas duas categorias de pessoas, explicita-se que "os antigos livres” são geralmente mulatos, e os "novos libertos", em geral, são negros.

A problemática de uma antiga ou de uma nova liberdade somente pode ser colocada em um ambiente colonial escravista como corolário da racialização das relações de trabalho. Não se liberta a um "branco", a liberdade é uma marca intransmissível de seu ser. Antigos ou novos libertos supõem a criação do negro ocidental como categoria social significativa. São subprodutos da fabricação deliberada do trabalhador colonial e não uma passagem obrigatória do desenvolvimento humano.

Se esses personagens não existem fora de um marco colonial e se os europeus, seus inventores, são os únicos a vê-los, é justo se perguntar: o que as demais pessoas percebem? Veem-se rodeadas de Ibos, Congos, Mandingas, Toucouleurs, Peuls, Haussás, de pelo menos 24 diferentes grupos que utilizam seus próprios critérios para se identificar. Essas pessoas têm projetos de vida totalmente

\footnotetext{
${ }^{10}$ A sequência dos fatos históricos que usualmente se registram - desde a criação da Legião da Igualdade à chegada de Toussaint na cena política, a derrota de Rigaud na Guerra do Sul, o regresso dos líderes libertos (antigos livres) com Leclerc e a derrota de Toussaint, até a reunião de Plaisance entre Dessalines e Pétion - se localiza na problemática colocada pela Revolução Francesa, na qual o alcance das demandas dos "escravos" é e permanece invisível no que se refere ao alcance de suas demandas.

${ }^{11}$ As declarações de Vincent Ogé são inapeláveis: "Je ne ferai pas soulever les ateliers; ce moyen est indigne de moi. [...] Lorsque j’ai sollicité à l'assemblée nationale un décret que j’ai obtenu en faveur des colons américains, [...] je n'ai point compris, dans mes réclamations, le sort des nègres qui vivent dans l'esclavage" (ARDOUIN, 1958, p. 34) e se completam com a de seu discurso proferido em frente ao Club Massiac: "Si l'on ne prend pas les mesures les plus promptes, les plus efficaces; [...] et voilà le sang qui coule, voilà nos terres envahies, les objets de notre industrie ravagés, nos foyers incendiés, voilà nos voisins, nos amis, nos femmes, nos enfants égorgés, mutilés ; voilà l’esclave qui lève l'étendard de la révolte ! Les îles ne sont plus qu'un vaste et funèbre embrasement; le commerce est anéanti ; la France reçoit une plaie mortelle, et une multitude d'honnêtes citoyens sont appauvris, ruinés : nous perdons tout." (MADIOU, 1989, p. 72-73).
} 
desvinculados à plantation, ${ }^{12}$ embora não os possam realizar enquanto o sistema dominante estiver vigente. Existem em Saint-Domingue atores sociais - e muitos deles que veem seus próximos mais além de qualquer evolução baseada sobre sua pretensa essência ou sua pigmentação.

Essa visão da pessoa humana que se imputa aos trabalhadores cativos como um mínimo denominador comum supõe uma história compartilhada. Essa exigência lógica encapsula talvez a diferença mais importante entre os haitianos e as populações originais da América, Ásia e da África. Estes últimos grupos humanos convivem séculos e séculos antes de se encontrarem com o Ocidente, enquanto que os haitianos nascem no processo de resistência ao genocídio e ao etnocídio. São inventados no seio do Ocidente e jamais existem por si só. Seu vínculo com a metrópole francesa é constitutivo e as minorias significativas não conseguem se imaginar sem este alter ego. A entidade que os haitianos constroem diariamente se afasta do Ocidente sem jamais completar o corte do cordão umbilical, mas, no cruzamento de caminhos, tudo indica que se fabrica uma identidade e uma solidão em uma estrada sem saída.

Não se trata de considerar tais circunstâncias como uma vantagem ou uma desvantagem. Trata-se simplesmente de apreciar a peculiaridade e a complexidade da história haitiana e as inovações constitutivas do grupo humano. No processo de luta contra impérios coloniais infinitamente mais poderosos que eles, a impressionante variedade de grupos étnicos acaba se fundindo e inventando uma nova identidade étnica em oposição à definição ocidental do negro como trabalhador colonial. Supera a racialização das relações de trabalho e inventa, em um tempo curtíssimo, outro negro distinto do negro europeu.

Por haver visto o dia no seio do mundo ocidental, esse novo personagem inclui o próprio "branco" em sua definição de si. No Haiti, "toda pessoa é uma pessoa" (tout moun se moun $)^{13}$ e toda pessoa é um "negro". Uma definição pelo estilo não é exportável para as sociedades

\footnotetext{
${ }^{12}$ As identificações étnicas tendem a classificar os cativos escravizados de acordo com supostas aptidões ao trabalho de seu grupo de origem.

${ }^{13}$ Tout moun se moun é um provérbio que representa uma das variantes da cultura haitiana que indica um princípio valorativo fundamental em uma cosmovisão radicalmente igualitária da vida social. (Nota do autor a pedido da tradutora)
}

capitalistas ocidentais. O negro haitiano e o ocidental se impugnam reciprocamente por pertencerem a mundos que se rejeitam.

A transformação do trabalhador colonial em uma simples pessoa sem horizonte predeterminado - por uma pretensa filiação com Cam, filho de Noé e pai de Canaã - se produz durante a conversão de Saint-Domingue, a colônia de exploração, em uma colônia de povoamento chamada Haiti. Observar a apropriação do território nacional, ou seja, o processo mediante o qual os deportados e seus descendentes se tornam "habitantes" ou "colonos", permite entender as características, as rupturas e o funcionamento interno de um estado nacional particular, assim como suas vinculações com suas elites e o mundo exterior. Por essa via, se esclarece também quão inadequado e inadaptado para o capitalismo é o conceito de homem que produz o haitiano.

Da mesma maneira em que não escolhem as circunstâncias em que nascem, os haitianos não decidem ser independentes. Ou se acomodam um por um e, como libertos, criam espaços de expressão e de reprodução dentro do sistema de plantation escravista, ou derrotam coletivamente um regime que exclui a grande maioria e que ao final os ameaça ao extermínio. No momento em que a insurgência geral vai tomando a via pública, nos anos de $1790^{14}$, e que no final da década, a reação napoleônica quer retroceder às normas anteriores a $1789^{15}$, os libertos de maior tradição e aqueles que emergem dos campos de batalha carecem de alternativa que não seja o caminho da independência.

Se o exército expedicionário houvesse derrotado o exército indígena, nenhum descendente dos cativos daquela época estaria contando hoje a história da insurgência. Os insurgentes de Guadalupe perdem a guerra e foram exterminados, conforme as ordens de Napoleão

\footnotetext{
${ }^{14}$ Em geral, se aceita como a data da insurreição geral a noite de 14 de agosto de 1793, como o início da Revolução Haitiana.

${ }^{15}$ Segundo Laurent Dubois (2004, p. 285 e seguintes; 2001, p. 112-134), desde maio de 1802 , se via chegar o restabelecimento da escravidão em Guadalupe e Saint-Domingue. Em várias correspondências, Leclerc solicitou a seu colega Antoine Richepance que não tomasse medidas precipitadas que colocassem em perigo a sua própria missão. No entanto, as notícias da vitória do exército expedicionário de Richepance sobre Louis Delgrès, a subsequente matança dos insurgentes, assim como o restabelecimento da escravidão se difundiram em toda a Saint-Domingue no segundo semestre de 1802.
} 
que manda trazer novos "negros” da África. Como consequência, o lema da revolução independentista: "Viver livre ou morrer", traduz um propósito, mas também um dilema que indica como o haitiano, no fundo, vive a história de suas relações com o Ocidente capitalista. Viver livre ontem, como hoje, pode significar morrer.

Embora a plantation escravista em Saint-Domingue tome as medidas necessárias para absorver a totalidade do tempo dos trabalhadores, as sementes de vida privada começam a florescer muito antes de 1804, com tanta maior pujança quanto mais extrema é a repressão. $\mathrm{O}$ conceito ocidental do negro como trabalhador colonial se coloca em xeque neste espaço exíguo de onde se inventa um ator social com direitos que não se podem conceder, sobretudo, o direito à vida e o direito de continuar sua descendência ${ }^{16}$.

Desde aquela época, apesar do alcance universal dessa definição da pessoa humana, ela não consegue ultrapassar o âmbito da vida privada haitiana e modificar o sistema político nacional ou colonial. O Ocidente, por intermédio do Estado, controla os recursos ao alcance do trabalhador haitiano, e se este se adapta às regras de utilização destes recursos, ou seja, se aceita viver como um trabalhador colonial, o espaço de desenvolvimento da sua vida e o de sua família se reduz cada vez mais. Gradualmente, deixa de ser um personagem capaz de transmitir sua visão de mundo e sua forma de ser para a sua descendência. O haitiano, tal e como se constrói no curso das guerras de independência - nesta visão, segundo a qual, todo o ser humano merece o mesmo respeito que seu próximo - não pode viver senão às margens do capitalismo: no coração do sistema, ele tem que desaparecer.

16 "Parmi tous les droits individuels, le droit à la sûreté a donc force de monopole. Il est le seul incessible et surtout, il est le seul droit civil. Dans l'État de nature, la sûreté n'est qu'un désir, une aspiration ou une tension de l'individu, non une réalité. Homo homini lupus, l'usage anarchique et collectif du droit de glaive menace constamment l'intégrité physique de chacun. Dans létat civil en revanche, la confiscation par le souverain des actes de guerre, le monopole de l'épée de justice, instaurent la sûreté individuelle par la sécurité juridique. Létat civil réalise un droit qui demeurait virtuel à létat de nature. Est ainsi fondé, à l'intérieur du droit politique, un droit de l'homme et du citoyen au sens moderne du mot ; un droit qui est en même temps naturel et civil". (KRIEGEL, 2003, p. 86-87).

\section{Saint-Domingue e Haiti}

A concepção de cidadão em conjunto com outros, que se elabora no transcurso das lutas independentistas se choca, desde o início, com os interesses de classe das elites dirigentes, interesses que, depois de 1804, somente podem satisfazer na medida em que ressuscitam o trabalhador colonial. Daí saem os denominadores comuns das estruturas políticas coloniais e "nacionais".

A semelhança entre a estrutura política de SaintDomingue e do Haiti não pode passar despercebida ${ }^{17}$. Com as companhias comerciais, o Estado francês, por um mecanismo ou outro, apropria-se de um território e tem total controle sobre as pessoas que recruta para viver nele. $\mathrm{O}$ direito que lhe assiste vem da força de suas armas e de seu êxito nos campos de batalha. Sua vontade é a lei. Por razões que não vêm ao caso mencionar neste momento, outro exército, o exército indígena, põe fim a esse poderio e se estabelece também pela força das armas e por seu êxito nos campos de batalha.

Por conseguinte, enquanto fonte do poder em uma ou outra entidade política, não é possível encontrar qualquer diferença. Nenhum desses estados tem ou negocia um mandato com a população que governa. Como as companhias comerciais do século XVII, o Estado de 1804 se declara proprietário de quase toda a totalidade das terras e as distribui a quem lhe interessa ${ }^{18}$. Nega o direito dos trabalhadores de dispor de sua vida de acordo com sua vontade $^{19}$ e lhes assenta sobre as plantações. Dessa forma, os direitos das pessoas à segurança pessoal, à apropriação de seu corpo, de seu tempo e de seus movimentos se conformam segundo as vontades do Estado e dos organismos que dependem exclusivamente dele.

${ }^{17}$ Não se trata de uma semelhança formal ou de organização, como nota B. Ardouin (1853, p.8-9), mas de um parentesco lógico ou filosófico que une ambos os regimes. Em relação ao governo colonial Ardouin escreve: "Il n'y avait pas d'administration: le militaire dirigeait tout. [...] Ainsi était réglée l'organisation de ce gouvernement colonial qui [...] a exercé une si grande influence sur les gouvernements qui lui ont succédé dans la suite des temps.

18 Também compete às autoridades militares cancelar uma concessão que não se cultiva a partir de um informe da polícia rural, visado pelo Juiz de paz (art. 17 e 18 do Código Rural de Boyer). Gérard Barthélémy (1996, p. 58) o qualifica sabiamente de "Estado Comandante".

19 À questão: 'Qu'est-ce qu'un esclave?', legistas e doutrinados clássicos responderam: "C’est un homme privé du droit parce que dépossédé du droit de s'approprier les choses et d’abord sa propre vie". (KRIEGEL, 2003, p. 280). 
Em 1804, o Haiti e o Estado colonial prévio são estados bandoleiros, frutos da violência e que se mantém pela força bruta ${ }^{20}$. Suas autoridades políticas são igualmente despóticas. A formação nacional, desde logo, outorga alguns objetivos de gestão do poder opostos ao do grupo colonial do estado metropolitano, mas os mecanismos específicos de gestão e de direção são similares. $\mathrm{O}$ autoritarismo do Estado nacional se vislumbra desde os regulamentos de cultivo de Toussaint que o Estado se encarrega de pôr em prática até o final do século XIX, sem modificações substanciais em sua filosofia.

Esta constatação em si não acrescenta novos elementos à discussão. Price-Mars (1919, p. 92-93) destaca categoricamente:

De fato, $[\ldots]$ o Estado ao tomar posse por direito de conquista da maior parte do solo para fazer distribuições en blocos ou em parcelas a seus favoritos, seja a título de doações nacionais ou como terras arrendadas [...], cria novos privilegiados, que reforçam os vestígios das antigas classes que sobreviveram à tormenta revolucionária.

O miolo do problema não é a injustiça da distribuição denunciada por todos os militantes favoráveis a uma reforma agrária. Trata-se da validação insidiosa dos princípios que guiam a diligência do Estado e que colocam em evidência seu caráter profundamente anti-nacional e neocolonial.

A meu ver, a elite haitiana - e particularmente a elite intelectual em seu conjunto - não questiona o direito do Estado de distribuir as terras sem nenhum princípio moral. A proteção das propriedade coloniais, entendidas como legítimas, e a preferência dada aos oficiais do exército na distribuição de terras parecem senso comum. A partir disso, estariam os excluídos na obrigação de aceitar a legitimidade desta divisão, assim como a subordinação de que se depreende? Sua inconformidade mereceria as sanções previstas por lei? Poderia esta lei jamais expressar suas aspirações e necessidades? Sobre estes silêncios de

\footnotetext{
20 "Bodin désigne les colonies de Charles Quint au Pérou, comme seigneuriales. [...] D’acquisition ou de brigandage, la seigneurie est récusée parce que le droit ne nait point de la force et que la justice ne sétablit par sur la guerre. Écoutez les accents rousseauistes de Loyseau: 'Son droit est encore plus difficile à fonder en raison parce que les seigneuries ayant été du commencement établies en confusion, par force et usurpation, il a été depuis comme impossible d'apporter un ordre à cette confusion, d'assigner un droit à cette force, de régler par la raison cette usurpation." (KRIEGEL, 2003, p. 57).
}

nossos intelectuais sobre o caráter do Estado descansa a infranquiável distância que separa nossas elites das massas e não permite traduzir na prática política uma mínima concepção de bem comum. Explica em si mesma a impossibilidade de formular um contrato social.

Um governo fundado sob a lei da espada supõe que os governados são seres, de uma forma ou de outra, inferiores e incapazes. A oligarquia que lidera a revolução independentista compartilha essa concepção. No entanto, alguns de seus membros, dentre os quais Dessalines, apreciam alguns direitos inalienáveis: o direito à propriedade, particularmente. Ao se colocar o problema da divisão de terras, antes pertencente à França, Dessalines desafia a tendência dos libertos de monopolizá-las ${ }^{21}$. De acordo com a visão de Dessalines, compete ao Estado proteger o acesso à terra dos antigos cativos. Seja como for, nesse pensamento, existe uma comunidade de interesse entre o Estado e a sociedade e um espaço de negociação política. Depois da Pont Rouge, onde Dessalines perdeu a vida, nenhum chefe de estado haitiano levantou essa bandeira, e nenhum intelectual questiona a razão de ser da discriminação contida nas áreas distribuídas aos antigos cativos. Na Pont Rouge, sociedade e estado dividem caminhos e nascem as "pessoas de fora”, os excluídos ${ }^{22}$.

Depois do governo de Dessalines, que durou apenas dois anos, o Haiti se dividiu em Reino do Norte e República do Oeste. São duas formações despóticas, apesar de suas características formais diferenciadas. Entretanto, Christophe, no Norte, rejeita inclusive o princípio de uma negociação com a França para o reconhecimento da independência. Dirige um Estado que se quer soberano e

\footnotetext{
21 "Si les élites noire et mulâtre, au lendemain immédiat de l'indépendance, ont des aspirations concurrentes, elles sont toutes deux opposées à la décision du premier chef d'État, Dessalines, d'annoncer la vérification des titres des biens fonciers." (GAILLARD-POURCHET, 2003-2004, p. 29).

${ }^{22}$ Tudo indica que a Pont Rouge poderia ter sido o símbolo do lugar a partir do qual as duas frações da elite poderiam ter firmado um pacto de alternância no poder. No entanto, tiveram de desvincular a negociação política da gestão econômica da sociedade, devido ao total rechaço das classes trabalhadoras da fórmula de economia de plantation promovida por ambas. Nessas circunstâncias, tornou-se difícil institucionalizar um método de chegada ao poder. A assistência de clientelas reduzidas e inconstantes, por sua própria definição, não se pode regular. Sem passar pela gestão da riqueza material, não poderiam os libertos nobres e os recém-chegados à condição de liberdade encontrar um espaço que pudessem negociar a gestão do poder.
} 
que não admite nenhuma potência externa suscetível de restringir, limitar ou de autorizar sua autonomia.

Ao negar a quem quer que fosse o menor direito sobre o Estado haitiano, Christophe inaugura um conjunto de relações políticas que potencialmente deveriam desembocar em uma aproximação significativa entre o Estado e a sociedade. A rejeição das negociações com a antiga metrópole promete uma evolução em direção ao exercício da soberania nacional, na medida em que se entende por estado soberano aquele em que a autoridade política suprema se submete somente a sua própria lei. Para assegurar o apoio dos sujeitos do reino em um caso de conflito armado, o Estado teria que lhes garantir certos direitos. Por essa via, o Estado do norte construiria sua legítima supremacia. Trata-se potencialmente de um estado de direito que acabaria por transcrever nos textos da lei a satisfação das necessidades da população.

Não obstante, a reconstrução da economia de plantation patrocinada por Christophe indica que, depois de 20 anos de reinado, não se produz nenhuma aproximação relevante entre Estado e sociedade. A promessa de soberania não frutifica, já que a plantação de gêneros de exportação, com exceção da fórmula proposta por Polverè $^{23}$ supõe a racialização das relações de trabalho, ou seja, a fabricação sistemática da inferioridade do trabalhador agrícola. Nenhuma negociação entre estado e sociedade pode florescer nesse tipo de economia.

Por outro lado, na política de Dessalines, a necessidade de uma melhor distribuição da terra se apresenta como uma exigência normativa ou de direito. A República de Pétion distribui parcelas por razões práticas de estabilidade política. Dentro dessa mesma orientação pragmática, o Estado que Pétion dirige, e depois dele Boyer, aceita a negociação com a antiga metrópole e solicita inclusive que autorize a sua existência, levantando assim o enorme problema de sua legitimidade como estado nacional.

Os "republicanos" do Oeste, ao se sentarem à mesa de negociação com a antiga metrópole e, pior ainda, ao oferecerem pagar uma indenização aos colonizadores por lhes haver empobrecido, fazem retroceder a independência conquistada em 1804. Pela mesma via, referendam seu

${ }^{23}$ Ver Gérard Barthélémy, "Le travail sous haute surveillance" (BARTHÉLÉMY, 1996, p. 91 et seq.). próprio direito às plantações e aos escravos que trabalhavam nelas antes do corte fatídico. Escolhem o apoio da França para sobreviver e conservar seus privilégios, em vez de apostar, como Christophe, em uma eventual negociação do apoio da população insurgente.

Até hoje pesa sobre os ombros do país a aceitação do negro como trabalhador colonial, totalmente contra a filosofia das lutas revolucionárias que se desenvolveram de 1790 a 1804 . O reconhecimento da dívida da independência é não só um reconhecimento do direito da França sobre Saint-Domingue e seus escravos, mas antes de tudo, um reconhecimento da inferioridade do negro e de seu dever de servir aos "brancos" e aos mais "brancos" de pele e de espírito. O país acabou pagando a dívida da independência, a dívida financeira, não obstante suas elites terem ainda uma dívida moral a pagar, não à França, mas aos insurgentes de agosto de 1790, já que todas elas concederam durante 200 anos a inferioridade à população haitiana.

Pelo caminho que tomam as elites, a supremacia do Estado não tem fundamento de direito, já que reside fora dele e se alimenta somente na preponderância das forças armadas. A existência do Estado é simplesmente necessária e prática, fora de toda ética política de corte nacionalista. Os direitos dos cidadãos seguem sendo aqueles que toleram a razão de Estado. Nesse marco de oportunismo inicial, floresce a opacidade do sistema político haitiano. A fonte de seu poder escapa ao cidadão comum cuja participação ou cujo compromisso político carece de sentido e de lógica em médio e longo prazo.

No Norte, como no Oeste, para explorar os recursos que distribui à oligarquia de plantadores e de oficiais do exército, o Estado pretende se apoderar da mão de obra disponível mediante o uso da força bruta. A manutenção da racialização das relações de trabalho serve de pilar para o Código rural de Boyer, promulgado 25 anos depois da Independência e, sob forma apenas mitigada, o Código rural de Geffrard, outros 30 anos mais tarde, volta a institucionalizá-lo. Em outras palavras, meio século depois da Independência, o Estado haitiano mantém o curso traçado pela metrópole colonial. A ocupação norte-americana fixa definitivamente o papel de trabalhador colonial que se refere imediatamente à população, sem que se levante a mais tímida voz nas classes dirigentes.

Dessa forma, além de conservar o caráter civilizador do estado ocidental, o haitiano quer se disfarçar de 
conquistador de sua própria população. Como todos os impérios coloniais na América, seus fundamentos manifestos são a cruz e a espada. Não reconhece a liberdade de pensamento e de religião. É dono de bens e de gentes, não é caudatário da justiça, é avesso ao judiciário, não reconhece as liberdades civis nem os direitos políticos e ignora a segurança pessoal e a liberdade do cidadão quando limitam seu funcionamento normal.

O reino de Christophe está mais próximo ao estado de direito, porque está em posição de avançar em direção à institucionalização de sua soberania. Entretanto, sua base econômica não deixa espaço para negociar uma participação popular e seu intento se desmorona depois de duas décadas. A República do Oeste se assemelha aos estados democráticos do estilo ateniense ou norte-americano $^{24}$, nos quais os hilotas trabalham para permitir aos "cidadãos" que se dedicarem de corpo e alma à política. Como o estado republicano carece de recursos humanos para exercer a violência extraeconômica que implica na sua política trabalhista, os latifúndios se tornam tesouros e a agricultura de plantation, a grande cultura, desaparece da economia nacional.

\section{As vítimas de 1804}

Uma instituição faz a ponte entre a vida colonial e insurgência destruiu as fortunas que arrecadaram com os trabalhadores coloniais de sua propriedade. A perda da pérola das Antilhas os afeta tanto como os colonos da metrópole.

São, pois, esses trabalhadores coloniais, liderados por libertos de primeira geração, a causa da desgraça desses ricos plantadores. A aliança dos "negros e mulatos" - leia-se libertos da velha tradição e libertos de primeira geração - é um matrimônio de conveniência provocado pela precipitação do general Richepanse, quem, segundo Leclerc, implementa em Guadalupe, de maneira prematura, a revogação do decreto de concessão geral de liberdade aos escravos e toma uma série de medidas contra os "homens de cor". Esse desenvolvimento impede a conservação da lealdade dos libertos da velha tradição e de controlar a insurreição. Estes libertos não participam na Revolução de 1804 como agricultores, mas como seres humanos ameaçados pelo genocídio ordenado pelo Primeiro Cônsul.

Diante disso, depois da independência, os que conseguem ou reforçam sua liberdade individual dentro de uma sociedade escravista nos campos de batalha não têm como conservar sua recente ascensão social fora de uma economia de plantation. Compartilham com os libertos da velha tradição o mesmo interesse na exploração dos trabalhadores coloniais, com a diferença que sendo os autores - pelo menos intelectuais - da destruição das "riquezas" coloniais não podem deixar de ser extremamente cautelosos com a antiga metrópole. A aliança de "negros" e "mulatos" é um acordo contra a França, mas não necessariamente um acordo em defesa dos trabalhadores cativos. Por isso, é impossível encontrar um ponto de quebra entre os interesses econômicos de "negros" e "mulatos", posto que ambos os grupos "de cor" defendem esses interesses às expensas da população trabalhadora. A questão de cor é uma cortina de fumaça que engana somente aos que querem se enganar.

Ao enfocar a Revolução Haitiana a partir da visão de que é lógico atribuí-la à maioria dos cativos que a levam a cabo, se está em posição de avaliar a envergadura das mudanças que brotam do movimento, sem se deixar enredar nos interesses e nas possibilidades de gestão dos líderes políticos, todos "antigos libertos". Diagnostica-se, em outras palavras, a discrepância entre as conquistas e as necessidades da população, por uma parte, e, por outra, os objetivos e as políticas do estado que dirige uma 
elite historicamente situada e sem vínculos estreitos com as massas.

Nota-se neste trabalho que o levantamento de agosto de 1790 não busca uma distribuição mais equitativa das riquezas coloniais e uma melhora dos níveis na sociedade escravista ${ }^{25}$. Os insurgentes objetivam o sistema de plantation e a racialização das relações humanas na qual se assentam, ou seja, desafiam a própria maneira de produzir riqueza e o que se considera como tal em dito sistema. Produzem uma nova definição do negro em uma filosofia do homem ${ }^{26}$ a qual, rapidamente, arquiva os libertos e, mais tarde, seus herdeiros.

Valeria a pena investigar os traumas causados nos libertos o levante geral, bem como os estratagemas que estes levaram a cabo para eliminar a memoria deste cataclisma que pôs por agua abaixo as suas mais sólidas convicções. Os fazendeiros metropolitanos ou deixam o país, acompanhados de mais de um fazendeiro liberto ou foram degolados depois de 1804. Mas, o que acontece com os fazendeiros libertos que devem dividir o poder com aqueles que acostumaram a considerar como selvagens? $\mathrm{O}$ que aconteceu com os que recém ascendem ao estrato de libertos quando enfrentam a resistência obstinada daqueles que outrora obedeciam cegamente as suas ordens? O pânico que causa aos libertos da velha tradição o levante geral ou a irritação que causa os recém-chegados provocam manobras ditatoriais dos oprimidos que podem ser lidas no pano de fundo dos textos da lei e na promessa de sociedade do Estado haitiano.

A independência resulta de uma tripla fratura da qual somente se registra e se celebra uma: a derrota da França. Ao cortar seus vínculos imediatos com a França, os heróis da independência defendem e conservam seus privilégios coloniais, inclusive aqueles que conquistaram depois de 1790. Asseguram sua posição social ao infligir uma derrota aos "bandos de escravos fugitivos". Ato contínuo e nessa mesma defesa de seus interesses, constituemse os únicos encarregados de implementar a missão civilizadora que pretende desculpar a servidão e, nesse contex-

\footnotetext{
25 "Il était également naturel que la classe des affranchis [...] cherchât à profiter de la révolution de la mère-patrie pour améliorer sa position sociale et politique, trop humiliante, trop avilissante, pour des hommes qui possédaient des lumières, des capitaux et des propriétés." (ARDOUIN, 1853, p. 27).

${ }^{26}$ Esta filosofia se resume na máxima: Tout moun se moun, ou seja: as pessoas humanas se equiparam e se equivalem.
}

to de um estado nacional "soberano", justificar o caráter autoritário de sua liderança.

A terceira fratura provém do distanciamento entre dois grupos de interesses distintos que compõem as elites e aos quais já se fez referência neste trabalho. É conveniente nos determos sobre esse processo que reabre as portas à influência da antiga metrópole.

No exército expedicionário que Napoleão despacha para pôr fim à rebelião que Toussaint L'Ouverture encabeça, cabe distinguir entre seus oficiais e os metropolitanos, os dois grupos de interesses coloniais referidos: um setor de libertos da velha tradição, procedente de famílias de fazendeiros ${ }^{27}$, e um setor de recém-emancipados que sobem na hierarquia militar no momento do levante geral. A maioria destes alcança altos cargos militares sob as ordens de Toussaint L'Ouverture ${ }^{28}$, enquanto que os libertos tradicionais - ainda que não necessariamente endinheirados regressam à colônia no contingente expedicionário depois de terem sido derrotados por Toussaint.

Alcançada a independência da França e vencidos os "bandos de escravos fugitivos", produziu-se a terceira quebra significativa com a derrota que os libertos da velha tradição dão de gorjeta aos recém-chegados à liberdade. O golpe de estado ao governo de Dessalines e o golpe parlamentar ao de Henry Christophe ${ }^{29}$ completam a captura do poder pelos libertos tradicionais, liderados por Alexandre Pétion e, em seguida, por Jean-Pierre Boyer.

A derrota dos que tiveram que subir por conta própria a escala social abre a porta à hegemonia do segmento dos fazendeiros formado por libertos da velha linhagem. Estes não experimentam nenhuma dificuldade para absorver os recém-chegados no projeto de sociedade deixado pela colônia. A rivalidade que a historiografia clássica registra entre "negros" e "mulatos" é simplesmente a interminável disputa entre ambas as facções da elite

\footnotetext{
${ }^{27}$ Uma maneira prática e sem dúvida um pouco restrita de determinar os que pertencem a esse grupo consiste em assinalar aqueles que se afastaram do resto da "gente de cor", ao solicitar que os direitos do homem se aplicariam aos libertos nascidos de pai e mãe libertos [...]. Eram 400 sobre um total de 20000, de acordo com Luis Sala-Molins (1987, p. 262).

${ }^{28}$ A batalha de conquista do Forte La Crête à Pierrot, anterior à capitulação de Toussaint, é a representação histórica gráfica dessa fissura.

${ }^{29}$ Ver Mirlande Manigat, Il y a 200 ans était créé le premier Parlement haïtien.distribuído na web pela RDNP3 News r.benodin@ att.net, em 9 de janeiro de 2007. (MANIGAT, 2002).
} 
para liderar a missão civilizadora da França e aproveitar as prerrogativas que derivam daí, a saber, dos frutos do trabalho forçado imposto aos excluídos em troca de seu eventual progresso.

A Revolução de 1804 causou duas grandes vítimas sobre o território nacional. Primeiro, os libertos de estirpe que perderam toda a sua fortuna, incluindo seus escravos e, em seguida, os libertos de primeira geração que conseguiram sua ascensão social graças à revolução, mas que não conseguiram se sustentar em um degrau tão alto por causa da própria revolução. Os únicos ganhadores foram as massas que se desfizeram de suas correntes. Não obstante, não puderam contar com a simpatia dos francófilos e muito menos com seu apoio.

\section{A promessa de 1804: Haiti e África}

Diante disso, no marco das mudanças estruturais que a metrópole provoca, a Revolução Francesa não pôde integrar o conceito de escravo em seu ideário. Robespierre declara que a simples menção dessa palavra imunda é um insulto à Convenção. Então, em vez de falar de escravos, a assembleia batiza os cativos estrangeiros de "africanos". 30 Permite assim aos fazendeiros de Saint-Domingue descobrirem um recurso muito prático para se referir aos trabalhadores coloniais depois da emancipação geral de 1793, quando todos teoricamente se tornam cidadãos franceses. Com essa designação, pode-se conservar sua estrangeiridade e não ter que lhes outorgar todas as vantagens da cidadania, como previra o Código Negro.

O lugar que a luta contra a desigualdade e a escravidão, tanto no seio da Revolução Francesa como entre os libertos de Saint-Domingue, cobra uma característica particular que salvaguarda o papel civilizador da colônia e de suas flagrantes ausências ${ }^{31}$ : a Revolução desafia o es-

${ }^{30}$ Vertus Saint-Louis, que aponta este dado, acrescenta que a denominação de africanos é um fato sociológico. Ver: SAINT-LOUIS, Vertus. Les termes de citoyens et Africain pendant la révolution de Saint-Domingue. In: HURBON, 2000, p. 75-95.

31 "Le plus grand malheur qui puisse arriver à ces pauvres Africains serait la cessation de ce trafic. Ils n'auraient alors aucune ressource pour parvenir à la connaissance de la vraie religion dont on les instruit à l'Amérique, où plusieurs se font chrétiens [...] Eh! Plût à Dieu que l'on achetât tous ces misérables nègres et qu'on dépeuplât l'Afrique". (D’une Dissertation sur la traite et le commerce des nègres publiée par Bellon de SaintQuentin en 1764) citado por SALA-MOLINS (2003, p. 62). cravismo, mas conserva o preconceito racial ou de cor ${ }^{32}$ nas tarefas que impõem às suas elites, a saber, elevar os "recém-chegados" à cidadania, ao nível da cultura e do ideário revolucionário.

Toussaint, em repetidas declarações abundantes nos textos escolares, exemplifica essa postura. Pergunta se a cor de sua pele menospreza sua coragem e sua inteligência. Sua Constituição - a de 1801 -, em consequência, retoma a distinção entre cidadãos e africanos sob os vocábulos de cidadãos e agricultores (SAINT-LOUIS, 2000, p. 87). A equivalência entre os termos "africanos" e "agricultores" rege a concepção dessaliniana e christofiana e essa identificação culmina no Código Rural de Boyer que trata de institucionalizar a categoria de cidadãos fixados na terra! $!^{33}$ O Código rural de Geffrard (1862) conserva a equivalência. ${ }^{34}$

A negação da mão de obra em viver na servidão levou à destruição do sistema de plantation, para a grande desgraça das elites. Dessa maneira, elas conservam ao longo da história um conceito muito particular dos "africanos", ou seja, daqueles que afundaram a agricultura, sua agricultura, latifundiária. Dizem comumente que o Haiti é a primeira República negra do mundo ou a primogênita da África. Esse pensamento disfarça um eurocentrismo bissecular ${ }^{35}$ e enclausura os vários mecanismos de acesso ao poder local, construídos às expensas dos "africanos locais".

${ }^{32}$ As identificações raciais se baseiam sobre a cor da pele. Para se referir aos cativos recém-chegados, os negros e os colonos falam de "negros novos" (nègres nouveaux) ou lhes designam por sua etnia. As identificações étnicas tendem a se utilizar, para classificar os trabalhadores escravizados, de acordo com supostas aptidões ao trabalho de seu grupo de origem.

${ }^{33}$ Com o passar do tempo, para se referir aos mesmos personagens, fala-se dos "habitantes", palavra cuja tradução em espanhol é a de 'colono'. Até os dias atuais, o setor se conhece como "a gente de fora”. A população do país compreende então a uma maioria de "pessoas de fora". Tudo indica que essa inferiorização é consciente.

${ }^{34}$ Nota o chefe do gabinete particular do presidente Geffrard que a regulamentação dos contratos entre os agricultores e seus empregadores no Código de 1823 derrogava ao direito comum e colocava os contratantes sob uma espécie de tutela legal. O Código de 1863 deixava as partes contratantes em total liberdade, mas as leis contra a "vadiagem" asseguravam uma oferta constante de mão de obra aos latifundiários. Ver os comentários a esse respeito em SAINT-AMAND (1921, p. V, 12, 13, 27-54).

${ }^{35}$ Para uma vasta documentação do eurocentrismo dos intelectuais haitianos, ver HOFFMANN (1990). 
A ideia que os haitianos da elite têm de si mesmos aliada a sua elevada autoestima não contradiz sua veneração superficial do africano. A imagem do continente de origem surge em condições históricas específicas e em um momento em que os interessados não sabem que são africanos. África, no século XVIII, não existe como uma fonte de auto-identificarão, como tampouco Europa, por certo $^{36}$. Por isso, quando do apogeu do imperialismo do século XIX, o Ocidente se apropria da África e o conceito se superpõe ao sentido que tem desde os tempos da escravidão em Saint-Domingue $e^{37}$.

Os membros da elite haitiana, sobretudo no fim do século XIX, se impõem à enorme missão de defender os africanos e a raça negra porque se consideram, de todos os negros, os mais ocidentalizados. Sua reverência à África não diminui o reconhecimento da Europa como fonte de toda cultura e de todo o conhecimento. A herança africana que reconhecem guarda um sabor colonial e escravista e o orgulho que provoca esconde o profundo propósito etnocida do Ocidente cristão. Nada do que se elabora a partir dessa herança tem o mínimo prestígio em seus projetos de vida, a não ser que o Ocidente lhe dê reconhecimento primeiro. A África que serve de matéria prima para a cultura nacional é a cara que os dirigentes haitianos tratam de ocultar desde sempre, gastando no processo o melhor dos recursos disponíveis.

\section{A promessa de 1804: Haiti e os ameríndios}

No calor da luta revolucionária, uma problemática aparentemente de alívio efêmero põe em evidência o rechaço do pensamento europeu e das categorias raciais utilizadas para lhes incorporar à sociedade. Em 1802, à raiz de sua vitória sobre as tropas de Toussaint L'Ouverture, o exército expedicionário integra o Estado-Maior.. Fazem parte das forças repressivas francesas todos os que, de sobremesa, irão ser os "pais" da pátria. Somente os bandos de marronagem e as subdivisões do exército sob o mando de oficiais boçais ou nascidos na África se negam a depositar as armas. Os futuros "pais" da pátria se lançam, para

\footnotetext{
${ }^{36} \mathrm{Na}$ língua haitiana, para se referir à África, se diz comumente Guiné.

${ }^{37}$ É útil mencionar, de passagem, que a França inventa o termo América Latina na mesma época.
}

a grande satisfação de seus superiores, em uma caçada aos escravos fugitivos.

Quando chegam à ilha notícias da revogação do decreto de emancipação geral em Guadalupe, o exército colonial se divide. Os libertos de velha linhagem e os "recém-emancipados" se unem aos escravos fugitivos para enfrentarem as tropas napoleônicas.

Nesse momento da luta, os insurgentes têm que se distinguir do exército expedicionário e encontrar uma maneira unívoca de se identificar, já que ambos os exércitos que se enfrentam usam o tricolor da Revolução Francesa. Depois de alguns vacilos, Dessalines, o general em chefe, decide chamar seu exército: o exército indígena. Frequentemente se entende que a palavra indígena alude à cor da pele dos soldados e, conforme avança o século XIX, esse sentido deturpado efetivamente vai se impondo. A corrupção do termo convém às elites, já que recupera a racialização das relações sociais próprias do colonialismo e serve para afastar o pensamento nacional de suas premissas originais extremamente significativas e discordantes.

Dessalines não confunde nativos ou crioulos com indígenas, conta nas fileiras do exército com uma maioria de boçais, ou seja, de pessoas nascidas na África. A palavra não alude, pois às pessoas com sangue africano, mas se utiliza em seu sentido próprio para se referir aos ameríndios. Em um primeiro momento, o general em chefe escolhe chamar o exército rebelde de o exército dos Incas; em seguida, opta pelo nome de exército dos Filhos do Sol, e finalmente adota o nome de exército Indígena. A decisão tomada, com conhecimento de causa, traduz uma postura política, provavelmente a do setor do exército que conheceu o cativeiro e que tem interesse em se identificar com a causa dos aborígenes, a saber, a dos libertos de $1^{\text {a }}$ geração.

Vale a pena recordar que, em 1776, Tupac Amaru II apresenta uma petição formal para que os índios sejam liberados do trabalho obrigatório nas minas do Peru. Ante a negativa da Audiência de Lima, decide tomar medidas mais radicais e, em 1780, encabeça a maior insurreição da história deste Vice-Reinado. Seu movimento se converte em independentista. O líder é derrotado e executado no dia 18 de maio de 1781, na Praça de Cuzco. Dessalines e seu exército escolhem, dessa forma, a proteção do peruano e se posicionam frente aos quatros séculos de Conquista. 
Para que não haja dúvida sobre o ideário de Dessalines, depois do massacre que ordenou contra os franceses, declarou que os habitantes do Haiti haviam feito o necessário para preservar sua liberdade. "Sim, devolvemos a estes verdadeiros canibais, guerra por guerra, crime por crime, humilhação por humilhação. [...] Salvei meu país, vinguei a América”. (DUBOIS, 2004, p. 301).

Nessa mesma ordem de ideias, é necessário trazer à lembrança que, ao concluir a luta pela independência, esses insurgentes, chamados de negros ou africanos, decidem ressuscitar o nome indígena da ilha e apagar sua apelação europeia. A apropriação do destino dos aborígenes da América e do nome que deram à ilha não somente marca um distanciamento deliberado da metrópole e do mundo ocidental em geral, mas também marca o terreno no qual se definem as relações humanas que guiam as decisões e ações dos revolucionários nesta época de mudanças estruturais. Para os trabalhadores revolucionários de Saint-Domingue, os conceitos desafiadores do comportamento nascem da convivência cotidiana e não de uma hipotética solidariedade "racial" ou de uma ideologia revolucionária importada. Essas formas de contribuição se revelam extremamente significativas para os libertos e, mais especialmente, para os de maior estirpe, mas não para as massas que não fazem idéia destes contextos.

Os intercâmbios entre a população ameríndia e os trabalhadores coloniais de origem africana datam da época do cacique Enriquillo e de Cristóvão Colombo. $\mathrm{Na}$ parte francesa da ilha, estes contatos continuam durante o desenvolvimento da marronagem do século XVIII, como documenta o livro de Jean Fouchard (1972), enquanto que Carlos Deive (1997) revela, na parte espanhola, uma variedade de sociedades de quilombos chamadas manieles, similares aos quilombos brasileiros e aos palenques cubanos ou colombianos. Remanescentes da população ameríndia conviveram, pois, com os cativos deportados durante largos períodos nas montanhas ou como trabalhadores e serviçais nos assentamentos europeus. ${ }^{38}$

\footnotetext{
${ }^{38}$ Convém ainda recordar que a ilha de Dominica, entre Guadalupe e Martinica, permanece livre de ocupação europeia até 1762, ou seja, quase três séculos depois da chegada de Colombo, e que em seguida passa sucessivamente às mãos francesas e inglesas. Da mesma maneira que chega a Saint-Domingue, notícias da insurgência peruana, é de se supor que os fatos da Dominica não são desconhecidos entre os líderes.
}

Como consequência, o conceito que os insurgentes e mais tarde os haitianos teriam da população indígena da América nasce das tarefas diárias, enquanto que a ideia que formam da África e dos africanos transita pela metrópole. Seus congêneres deixados na África e com os quais não conviveram constituem uma fonte de identificação à medida que a França assim diz ou, se preferirem, na medida em que as categorias coloniais são escolhidas para pensar. Sua visão se constrói na convivência com os aborígenes e não se pode equiparar com a ideia que fazem dos congêneres com os quais não compartilharam a vida cotidiana. De modo contrário às designações coloniais que insinuam a existência de formas de solidariedade epidérmica, os insurgentes se identificam a partir de resultados obtidos na luta conjunta com os obstáculos cotidianos.

A atitude americanista - embora não latino-americanista - de Dessalines não é passageira e é compartilhada por uma fração significativa da oligarquia haitiana. Dez anos depois do assassinato do Imperador, estipulou-se no Artigo 44 da Constituição de 1816: “Todo africano, índio e os que descendem de seu sangue, nascido nas colônias ou em países estrangeiros, que residir na República, será reconhecido como haitianos". (JANVIER, 1886, p. 117). Segundo Leslie Manigat, na Constituição de 1805 e, explicitamente, na de 1816 "e um novo jus sanguinis etno-ideológico havia nascido!"39

Em resumo, os trabalhadores colonizados de Saint-Domingue, ao terem de avançar rumo à independência, desafiam a visão ocidental da humanidade que entroniza o branco como o rei da criação. Apenas uma instituição do Estado faz a passagem do sistema político colonial ao nacional: o exército. Dita instituição carrega uma atitude enraizada de rechaço a certos aspectos do mundo europeu que se distribui de modo muito diverso entre a oligarquia dirigente e se expressa de forma ambígua ao longo da história nacional.

\footnotetext{
39 "La problématique de l'ethno-nationalisme haïtien. Haiti a fondé sa nationalité sur son appartenance ethnique : une nation noire et ceci a fait scandale au 19ème siècle. [...] Cet ethno-nationalisme imprégnait jusqu'au droit constitutionnel puisque nos pères avaient conçu un "jus sanguinis" fondé sur la race en admettant à la nationalité haïtienne tout individu issu de sang noir ou asiatique venant sétablir chez nous (Les deux cents ans d'histoire du peuple haïtien, 1804-2004, Réflexions à l'heure du bilan d'une évolution bi-centenaire (un inédit et 2 reprises)" (MANIGAT, 2002, p. 27).
} 
Em suas origens e pela própria vocação, a Revolução Haitiana nega a racialização das relações de trabalho formulada pelo Ocidente. No entanto, esse progresso ideológico constitui um peso que sobrecarrega, muito a contragosto, as elites políticas e econômicas. Por suas implicações nas relações com as potências imperiais e com a comunidade internacional em geral farão o impossível para que esse pensamento não influencie a política "nacional".

\section{A promessa de 1804: o estado-nação}

Na primeira metade do século XIX, o país, como os demais territórios do Caribe, carece de importância econômica para as potências europeias. Estas saem para conquistar os grandes espaços do globo, de modo que a elite dirigente gravita de uma autarquia inicial entre uma comunidade internacional, inóspita e indiferente, e um campesinato em formação, com recursos suficientes para derrotar os intentos de destruí-lo.

O modelo de estado de Christophe, montado em uma economia latifundiária de plantation, permanece vigente durante 18 anos, para em seguida se ver desbaratado e substituído pela agricultura aldeã. $\mathrm{O}$ modelo de Pétion carece de força política para criar uma oferta de trabalho servil; não pode reativar a plantation e propiciar a formação de latifúndios improdutivos. O Estado assiste impotente à transformação da colônia de exploração em uma colônia de povoamento durante a primeira parte do século. Trata-se de um aprofundamento do processo de independência, que vem se materializando com um radicalismo que a elite trata de se esquivar a todo custo, já que é prejudicial a seus interesses econômicos. Vê-se obrigada a buscar amparo no comércio e na administração pública.

$\mathrm{Na}$ segunda metade do século, enquanto o grosso da população, incluindo os baixos escalões do exército, ${ }^{40}$ consolida gradualmente sua apropriação do território, os estratos privilegiados das forças armadas se transformam em uma burocracia administrativa comum e corrente. A carreira militar se torna mais e mais decorativa e chega ao ponto em que líderes civis se vestem de generais, ao declararem sua candidatura à presidência.

${ }^{40}$ O Código Rural de Boyer encarrega especificamente a polícia rural de buscar os "vagabundos" que se escondem atrás do uniforme militar (art. 181).
Ocorre um período de estabilidade política de uns trinta anos (de 1874 a 1908) com governos que duram em média 5 anos cada. A ruptura original entre os libertos mais antigos e os de $1^{\text {a }}$ geração, sem que possa se cicatrizar, avança em direção a um modus vivendi, um estado-nação original se estrutura com suas instituições e os conflitos que animam sua dinâmica. (HECTOR; CASIMIR, 2003-2004, p. 35-64).

Ditos conflitos testemunham um desenvolvimento regionalizado autopropulsado de certo equilíbrio. Vai-se institucionalizando paulatinamente uma fórmula de divisão do poder e de alternância no governo que corresponde, grosso modo, às variações nas influências regionais. A província domina o panorama político descentralizado e o país está governado por um conjunto de notáveis, os quais, a cada mudança política de relevância, se reúnem no parlamento para renegociar sua posição no xadrez político. Essas negociações, desde sempre, não são democráticas, tampouco anárquicas. O caráter despótico do estado nacional diminui com sua descentralização $\mathrm{e}$ as agressões à soberania, muito freqüentes na época, $\mathrm{e}$ demonstram precisamente a defesa de um grau de autonomia que irrita as potências imperiais.

Naquela época, a atividade agrícola e o comércio de cada zona propiciam a riqueza do país, assim como o eixo de uma coesão nacional que não prejudica esse enriquecimento diferenciado. O Haiti experimenta um desenvolvimento endógeno e autocentrado paralelo à gestação de um sistema político e administrativo de crescente racionalidade. $\mathrm{O}$ apogeu da economia aldeã de contra-plantation acompanha a transformação do aparato estatal. A produção econômica supera a da famosa "pérola das Antilhas", salvo no reduto de produção de açúcar que tem algumas exigências incompatíveis com a visão nacional do trabalhador agrícola. O caminho sobre o qual desemboca a política diária funciona com resultados modestos, é certo, mas cumulativos.

O enfraquecimento das elites dirigentes dura apenas um século e não se completa devido à árdua resistência que os setores afetados opõem à consolidação da contra-plantation. Com efeito, se sugerimos que na luta anticolonial, os ibos, iorubás, congos, mandingas e outros perdem paulatinamente suas particularidades étnicas para se identificarem como haitianos, não podemos dizer o mesmo das vítimas dessas lutas: os libertos, tanto os mais antigos como os de $1^{\text {a }}$ geração. Esse setor perde 
sua nacionalidade em 1804, mas a França permanece sua mãe-pátria. (ARDOUIN, 1853, p. 27). O tipo de haitiano que constrói não inclui, em pé de igualdade, os antigos ibos, iorubás, congos, mandingas e a seus respectivos descendentes. Além disso, institucionalizam como única forma de melhoria dos níveis de vida e de mobilidade social ascendente, a participação nos mecanismos de exclusão do campesinato e de negação das obras culturais locais. Dita política antinacional que hasteia como um bilhete de entrada nos clubes patrocinados pela comunidade internacional, serve de justificativa às negociações da Concordata com a Igreja Católica e às políticas de "educação" pública. Utiliza-se inclusive em suas lutas anti-imperialistas, como as que levam a cabo o Dr. Rosalvo Bobo. ${ }^{41}$

Os recém-libertos que a luta armada expulsa sobre a cena política surgem do estrato de excluídos. Sua pujança, sua bagagem cultural e seus métodos de ascensão social contariam os interesses e os hábitos dos libertos antigos, núcleo original das elites residentes na colônia. O rechaço popular da política agrária colonial, o retraimento da comunidade internacional no início do século XIX e a construção de um estado nacional soberano fortalecem os recém-libertos - como Dessalines ou Soulouque - e inclusive os líderes de origem africana - como Pierrot - e colocam a embaraçosa necessidade de dividir o poder entre um número maior de oligarcas. Ademais, o desenvolvimento endógeno autocentrado da primeira metade de século, inevitável dada à perda do patrocínio metropolitano, acarreta garantias substancialmente menores de herança de status privilegiado e uma redução gradual das áreas de controle social que a oligarquia se reserva. Tudo isso explica a animosidade mal disfarçada que mancha as relações entre ambas as facções da elite nacional, mais conhecida na historiografia tradicional como "la question de couleur". ${ }^{2}$

41 "Dans le ressentiment envers l'Afrique, Rosalvo Bobo était allé encore bien plus loin. On a peine à croire qu'en 1908, s'adressant Aux progressistes, il ait pu les exhorter à effectuer les réformes nécessaires sans tarder, étant donné que: '[...] notre petit habitat est une injure pour le Nouveau Monde, étant le seul [...] à offrir asile à l'Afrique, c'est-à-dire au crime, à l'enténèbrement, à la barbárie". Aux progressistes haïtiens, St. Thomas: Imp. Fort de France, 1908, p. 11, apud HOFFMANN, 1990, p. 40.

${ }^{42}$ As interpretações tradicionais da história privilegiam as lutas entre as categorias coloniais de negros e mulatos. Uma das obras desse tipo mais conhecidas no Haiti é a de Duvalier (1968, p. 307-367). No exterior, um dos textos famosos é o livro de Nicholls (1985).
Com a chegada do imperialismo desenfreado da segunda metade do século XIX, as pressões sobre o estado haitiano se tornam insuportáveis e a eventualidade de uma destruição das elites, uma alternativa muito concreta. Nesse contexto, afina-se a perícia, referida anteriormente, no manejo do Estado, que chega a um nível exemplar de governabilidade. Não se incrementa a soberania nacional e muito menos se chega a impor o Império da lei aos dirigentes. Tampouco se promove algo que desenvolveria uma maior aproximação entre estado e sociedade, como uma maior consistência interna das negociações sociais, apesar da emergência de líderes de opinião mais e mais competentes, uma institucionalização progressiva de forma a dirimir os conflitos de interesses, uma configuração paulatina da ideia de bem comum que iria minguando as exclusões e impondo uma ética política. Pelo contrário, se reforça a vocação civilizadora das elites e se aprofunda a distância entre elas e as massas. Contudo, a cúpula da classe política demonstra uma maior sofisticação em matéria de administração pública.

Devido às barreiras à institucionalização de uma participação política crescente, as massas camponesas fazem valer sua presença intensificando o uso das baionetas, o qual deixa desamparadas as facções litigantes, tornam-nas mais vulneráveis e satisfaz somente às exíguas camarilhas no poder e enquanto estão no poder. Na segunda metade do século XIX, assim fragmentada em grupelhos efêmeros, usualmente sem apoios que ultrapassem os limites regionais, mas sem potência tutelar única, a elite se dedica a arbitrar o conflito entre o desenvolvimento endógeno que vem se processando, e a inserção do país nas aventuras econômicas imperialistas do fim do século XIX e princípios do século seguinte.

Recrudescem e as rivalidades entre os impérios vão se fazendo mais e mais contundentes entre os impérios coloniais e, com elas, as agressões da Inglaterra, França, Alemanha e dos Estados Unidos. Os franceses reagem ao avanço dos ingleses e dos norte-americanos no cenário mundial, originando a divisão bipartida do Ocidente entre saxões e latinos. Embala-se a expressão da América latina, toda católica, dentro da qual a elite intelectual haitiana acredita poder encontrar hospedagem.

Tal elite toma medidas para salvaguardar seus privilégios implementando o que se deveria chamar de 
"etnocídio antirracista". ${ }^{43}$ De fato, ao tempo que se dedica a promover a erradicação da cultura local pela Igreja Católica, escreve tratados científicos sobre a igualdade das raças humanas, em polêmica frontal com a Sociedade Francesa de Antropologia e o racismo científico que difunde. Assim, sua defesa da raça negra e da África se faz em nome do Ocidente capitalista e com as premissas desse mundo.

Os avanços na cultura dominante local, promovidos pela elite intelectual, contrastam com o retrocesso da posição de sua contraparte econômica durante as últimas décadas do século XIX. Os comerciantes haitianos, atacados por um lado pelos consignatários estrangeiros e seus consulados e, pelo outro, pelas massas camponesas descontentes ante a evolução dos preços no mercado internacional e, sobretudo os de café, tratam de defender seus interesses, buscando a proteção dos impérios coloniais ao contrair bodas com cônjuges expatriados. (GAILLARD-POURCHET, 2003-2004, p. 27). Incapazes de competir nos setores secundários e primários em plena expansão no mercado internacional, assistem de braços cruzados e sem maior preocupação o êxodo da força de trabalho para as plantações que os Estados Unidos vão implantando na região caribenha.

O eurocentrismo latino de ambos os segmentos da elite - a intelectual e a econômica, a de antiga ascendência e a de $1^{\text {a }}$ geração - constitui um poderoso elemento de identidade: serve para distingui-los nas esferas internacionais ao mesmo tempo em que indica seu alto status nas dimensões nacionais. Ao se refugiar em uma suposta latinidade, descobre na América Latina um nicho de localização. Essa saída não resolve sua participação na comunidade internacional, já que "América Latina", pelo próprio nome, participa de uma visão bipartida, toda ocidental, do mundo. As elites do país coincidem com essa

\footnotetext{
${ }^{43}$ A escravidão não implica em racismo. Yves Benot escreve (2003, p. 12): [...] le racisme n'a pas été à l'origine (de l'esclavage); les colonisateurs étaient tout prêts à prendre des hommes bleus, jaunes, voire blancs s'il s'en trouvait suffisamment pour satisfaire leurs exigences. Aux Antilles, ils auraient préféré asservir les Indiens arawaks ou caraïbes, mais leur violence les a fait disparaitre. Quant au racisme, remarquons que si, en tant que comportement désigné aujourd'hui sous cette rubrique, il s'est manifesté depuis longtemps, il n'existe en tant que théorie constituée sous couvert de prétentions scientifiques que depuis l'extrême fin du XVIIIe siècle et surtout le XIXe siècle; théorie agissante, on ne le sait que trop, mais il ne convient pas de l'antidater de manière anachronique.
}

posição, já que para eles o africano e o ameríndio somente têm valor como matéria prima a extrair de seus moldes arcaicos por meio de uma pretensa modernização.

O problema é que a América Latina se define a partir de conceitos coloniais que outorgam à cor escura da pele uma categoria de marcadores de selvageria e, por conseguinte, de índice de aproximação com o africano. Para seu desespero, as elites se veem designadas a posições subalternas ou condescendentes na maioria dos âmbitos internacionais, devido às suas características propriamente "raciais", e independentemente de seu "grau de cultura".

Contudo, elas se aferram a sua identidade latina particularmente durante a ocupação norte-americana, tanto por consequência de grosseiras humilhações importadas do sul dos Estados Unidos, e das quais não padeciam a partir da independência; como pelo apoio oferecido pelo continente sul-americano na luta anti-imperialista. Além de aproximá-las do mundo internacional, a "latinidade" lhes serve, no seio da sociedade local, para dificultar a mobilidade social ascendente das massas excluídas e para centuplicar a opacidade do sistema político.

\section{Nem latina, nem africana: só}

A especificidade (ou a solidão) haitiana se inicia antes da independência. Deve-se: 1) ao rumo tomado pelos fragmentos étnicos que o tráfico negreiro jogou de qualquer maneira na ilha e à medida que vão se apagando suas respectivas fronteiras no transcurso da luta revolucionária e depois dela; 2) aos vínculos ambíguos dessa luta com a Revolução Francesa que inspira aos libertos privilegiados da colônia mudanças tímidas, ao mesmo tempo em que cria uma conjuntura que facilita um desenlace favorável às demandas de revalorização e de dignidade das forças sociais emergentes; e 3) à ambiguidade de uma independência nacional que acarreta um profundo antagonismo entre seus dirigentes e as massas em rebelião.

Ademais, a elite, tanto no século XIX como no XX, engrandece a impressão de unicidade que guarda uma aproximação com a história nacional, já que, em vez de buscar alguma lógica às criações endógenas, é a primeira a visualizá-las como anômalas ou triviais. A desqualificação a priori dessas criações tem um impacto particular 
quando provém dos intelectuais, às exceções, como Jean Price-Mars ou Jacques Stephen Alexis, sendo escassas e não isentas de inúmeros matizes. ${ }^{44}$

Com essa predisposição negativa, a ciência social haitiana não nota que a façanha principal da Revolução de 1804, da qual não participaram os próceres, consiste em converter a colônia de exploração que é Saint-Domingue em uma de povoamento. Os cativos de ontem, - escravos ou "africanos", e logo "novos livres", "agricultores" ou "cidadãos atados a terra", e finalmente "habitantes" ou "gentes de fora" -, derrotam a economia e a sociedade de plantation, seja francesa ou haitiana, e criam uma economia e uma sociedade aldeãs, a partir das quais acabam coexistindo e se reproduzindo a totalidade dos que sobrevivem às guerras independentistas.

No entanto, se o povo haitiano derrota a oligarquia que tenta reeditar a economia de plantation, não pode impedir que esta tome medidas para reconquistar e assegurar sua hegemonia. A "reconciliação" com o Ocidente, conseguida por Boyer, recoloca a fonte de privilégios sociais fora da sociedade local, no patrocínio da comunidade internacional. Desliga o poder político da gestão das riquezas locais. Os resultados obtidos pela sociedade em suas atividades econômicas não afetam os administradores do estado, os quais, de fato, recebem seus mandatos da potência tutelar. O político tende a se limitar à gestão local do poder metropolitano.

O desmoronamento do Estado-nação se inicia nos últimos anos do século XIX. Na esteira da abertura do Canal de Panamá, os Estados Unidos decidem proteger a rota marítima que une suas costas atlântica e pacífica. Cuba, Porto Rico, Haiti e República Dominicana caem,

44 "Mais lorsqu'il (Price-Mars) constate que l'auteur (Verschueren) écrit à son propos: "Le Dr Price-Mars admire el vaudou et a beaucoup de sympathie pour ce culte", il laisse percer son indignation: 'Vous entendez bien !, s'exclame-t-il: [...] des barbares peuvent prétendre que j'accorde mes sympathies et mon admiration à de frustres manifestations d'animisme mêlées de magie et de sorcellerie [...] Nulle part cependant [dans mes livres] on y peut trouver une adhésion quelconque, encore moins une parcelle d'admiration pour ces croyances en tant que croyances. [...] Ce n'est pas le vodou, que j'aime, c'est la science qui s'en occupe. (Sociologie religieuse, pp. 18-21)" (HOFFMAN, 1990, p. 192). "Jacques-Stephen Alexis [...] se positionne lui aussi en ces termes: "Nos ethnologues, qui sont des hommes de science, ont pour devoir d'insister sur l'aspect d'arriération culturelle dont témoigne le vaudou", écrit-il dans Le Nouvelliste du 7 janvier 1958." (HOFFMAN, 1990, p. 195). uma após a outra, sob uma forma ou outra de administração norte-americana.

As elites recebem as tropas norte-americanas em 1915 com uma visão que se pode qualificar de pró-ocidental, antissaxônica, antiafricana e anticamponesa. A ocupação reorienta suas lealdades políticas ao incrustar nelas mesmas os oficiais de um exército, que forma parte integrante de seu corpo de fuzileiros navais. A inclusão da "Guarda Nacional" no exército de ocupação põe em prática e com maior êxito a estratégia inaugurada pelo exército expedicionário de Napoleão que absorveu ao Estado-Maior de Toussaint L'Ouverture. ${ }^{45}$ A diferença é que, dessa vez, os bandos de escravos fugitivos - conhecidos nessa época como cacos - não puderam ser medidos de forma isolada e, com certo impacto, a um invasor dessa envergadura para logo se beneficiar do apoio dos "libertos".

As elites que se concebem muito "cultas" e muito latinas ficam boquiabertas ao experimentarem, na própria carne, a contribuição norte-americana na fabricação do trabalhador colonial. Não tardam em expressar sua decepção pelo acordo que lhes dão de gorjeta. No entanto, sua frustração não impede que, apoiadas na bagagem ideológica racista que se maneja nos Estados Unidos, no início do século $\mathrm{XX}$, realizem seu sonho de afastar os camponeses de qualquer fonte de poder. Para isso, incrementam a validez dos indicadores de status como a cor da pele ou a "raça", o uso do idioma francês, a residência urbana e a prática da religião ocidental. Os governos da república fazem, com a participação ativa do interventor, todas as leis repressivas promulgadas pelos notáveis do século anterior, mas nunca postas em prática.

O destino das massas camponesas toma outro rumo. Inverte-se a transformação de Saint-Domingue em uma colônia de povoamento e se retrocede em direção a uma exploração até a morte da mão de obra com as

\footnotetext{
${ }^{45}$ A observação de Dante Caputto é uma triste evocação do tipo de exército que "governa" o país desde 1915: "High up on the wall, running the length of the table, was a series of photographs of the previous commanders of the FADH. (Fuerzas armadas de Haití). The faces in the top row were white! These were the U.S. Marines who had commanded the FADH during the U.S. occupation of Haiti from 1919 to 1935. 'What the hell are they doing there?' Pezzulo asked himself. [...] It said volumes about how the Haitian military saw their relationship to the United States. 'I don't think there's an army in the world that would put pictures of the occupying army in the headquarters of their general staff,' Dante Caputo said later." (PEZZULLO, 2006, p. 23).
} 
políticas de "desenvolvimento", inauguradas pelo capital norte-americano. Para sobreviver, números crescentes de camponeses tiveram que vender sua força de trabalho nos ambientes sociais estranhos onde não falam o idioma, não têm vida privada e familiar que possam regular e carecem de instituições comunitárias para lhes proteger. O trabalhador recobra seu caráter de estrangeiro sem direito nem amparo, exatamente como o cativo descartável do século XVIII. Conforme passam os anos, números crescentes de trabalhadores aumentam pela carência de alternativas nos barcos negreiros rumo às Bahamas e à Miami, ou nos ônibus que cruzam a fronteira, com a diferença que têm que pagar a passagem de seu próprio bolso.

Se, durante o século XIX, os camponeses têm uma participação apoiada nas tarefas políticas e pressionam em direção a um desenvolvimento endógeno autopropulsado, depois da derrota dos "cacos", toda a oposição política se faz nas cidades, dentro de marcos fixados pelo exterior e pelos herdeiros dos libertos, tanto da velha como da nova geração. Dessa maneira, consuma-se a desarticulação entre a sociedade civil camponesa ${ }^{46} \mathrm{e}$ um estado que se apoia em uma sociedade civil urbana, com sua opinião pública e seus meios de comunicação crescentemente integrados ao sistema global.

$\mathrm{O}$ século $\mathrm{XX}$ haitiano evidencia a incapacidade tanto da comunidade internacional como dos governos haitianos de modificar a situação de pobreza crônica que resulta de sua política sistemática de proletarizar o camponês, de excluí-lo de todas as tomadas de decisão e de toda participação política. No próprio processo de manter o campesinato a distância, os governos e as elites aumentam sua incapacidade de impor uma presença digna ao Ocidente, ampliam sua dependência, sua impotência e seu isolamento.

O êxodo de trabalhadores à República Dominicana se faz acompanhar da matança de um número que varia entre 12 e 40000 pessoas. ${ }^{47} \mathrm{~A}$ timidez da elite compete

${ }^{46}$ Entende-se por sociedade civil camponesa, a rede de instituições sociais encarregadas de satisfazer as necessidades da sociedade aldeã.

${ }^{47}$ No período que acompanha todo o século XXI, os haitianos foram sistematicamente dizimados na fronteira com a República Dominicana. O episódio mais conhecido e chocante da história foi em 1937 quando o então presidente dominicano General Trujillo ordenou o assassinato de uma só vez de 5.000 haitianos. A esse respeito, ver Rubén Silié (1998; 2002), Alan Belén Cambeira (1997) e Edwise Danticat (2000). Nota da tradutora. com a da comunidade internacional em registrar o massacre. Não se ouve falar de crimes contra a humanidade nem ontem, nem hoje. $\mathrm{O}$ mesmo acontece com a perseguição religiosa, no final dos anos 30 , patrocinada pela Igreja Católica e pelo Estado e assistida pelo exército. ${ }^{48}$

Ademais, como foi urgente contribuir com a Segunda Guerra Mundial, milhares de camponeses foram desalojados para a reconstrução dos latifúndios necessários ao cultivo da borracha e de outros produtos estratégicos. Resolver os problemas alimentícios das massas camponesas não parecia ter qualquer prioridade quando os "aliados" e "amigos" do estado - que obviamente não são "aliados" nem "amigos" do campesinato - necessitam de ajuda.

A partir de 1915, a ação política significativa se faz mais e mais opaca para a população e as tarefas políticas do estado se limitam essencialmente às negociações com os Estados Unidos e o resto da comunidade internacional. Os vínculos oficiais do país com a América Latina já passam pela Organização dos Estados Americanos, para a qual não são relevantes as demandas de participação no poder (empowerment) dos grupos oprimidos.

No outro extremo do espectro político, a vertente de ação levada a cabo por meio dos partidos e das centrais de esquerda não produz resultados importantes. A insurgência esquerdista dos anos sessenta não se irmana com os movimentos revolucionários estrangeiros de maneira a impactar as massas locais, já que carrega a mesma vocação missionária do Ocidente cristão, ou seja, a mesma avaliação negativa do campesinato e de suas possibilidades de entender o mundo em que vivem.

${ }^{48}$ Para ilustrar a cumplicidade entre o ocupante e a elite intelectual nacional e internacional, assim como o desprezo desta pela cultura local, basta dizer que não se pode apontar a medida certa em que os antropólogos assistiram, durante a primeira metade do século XX, às cerimônias vudu em seu "contexto normal" para elaborar, a partir disso a "observação participante", as obras consideradas contemporaneamente como clássicas. Tudo indica que para suas "observações participantes", os antropólogos convidaram os fiéis do vudu para celebrarem simulacros nos quintais de suas casas ou no Instituto de Etnologia, enquanto tomavam nota [...] (ver RAMSEY, 2005, p. 165-179). Por amor à ciência antropológica e a sua missão civilizadora, patrocinaram com seu silêncio ou sua cegueira os atropelos iniciados desde 1492. 


\section{Conclusão}

Com uma população aterrorizada e em total isolamento, a classe dirigente recicla e renova conceitos coloniais $^{49}$ para "dar um passo adiante" no século XX. No pós-guerra, a Revolução de 1946 não detém o retrocesso do estado nacional. As lutas pelo poder são levadas a cabo em torno da famosa "questão de cor" de modo que a problemática dos conflitos "raciais" se impõe à das relações entre culturas vigentes, igualmente importantes para o desenvolvimento da vida cotidiana.

Desse modo, a intenção de frear a involução experimentada a partir da ocupação americana acaba reforçando o eurocentrismo das classes dirigentes. Cada pretendido grupo "racial" se empenha em provar que é o mais apto para a missão civilizadora que assume em nome do Ocidente.

Essa atitude de fundo, expressa na busca do desenvolvimento econômico e social (WOLFE, 1981), casa com as propostas das famosas décadas para o desenvolvimento das Nações Unidas, que, somadas às políticas norte-americanas anticastristas, como a Aliança para o Progresso e a Iniciativa da Bacia do Caribe, exacerbam o círculo vicioso da pobreza assim como a subutilização dos estratos médios urbanos. Depois de mais de meio século de política desenvolvimentista e apesar da perícia de uma série de especialistas internacionais, o Haiti não passa de uma ilhota; mas ninguém questiona a política dos organismos internacionais. É mais fácil culpar os analfabetos: não têm voz.

O resultado disso é um êxodo incontrolável da força de trabalho que parece ser, neste início do século XXI, a única forma viável de inserção no chamado mundo moderno e a política oficial de desenvolvimento de todos: no governo ou na oposição. Nenhuma das plataformas políticas de nenhum dos partidos que competem pelo poder, antes ou depois da Segunda Guerra Mundial, menciona uma estratégia para pôr fim a essa sangria. Se uma elite não pode pensar em conter as massas dentro das fronteiras do país, que Estado soberano pode dirigir? A inserção do Haiti na comunidade global significa, até

${ }^{49}$ Os conceitos de superstição, analfabetismo, marginalidade... "modernizam" apenas as bases ideológicas (idolatria, selvageria, ignorância, irracionalidade de povos sem razão...) da racialização das relações de trabalho. os dias atuais, um isolamento crescente de um número também crescente de nacionais.

A involução do aparato estatal em direção às formas de despotismo desenfreado experimentou uma inflexão no final dos anos 70 com a Teologia da Libertação e o fastídio causado pela extensa ditadura duvalierista. Ocorre uma imensa mobilização do eleitorado, a partir da qual os segmentos sociais camponeses se encontram com os segmentos urbanos pela primeira vez no século XX. Porém, a mobilização se apaga como um fogo de palha, já que a elite intelectual não consegue imaginar uma fórmula de vida e de gestão política viável e caudatária do conceito haitiano da pessoa humana: Tout moun se moun. ${ }^{50}$

Confinados em seus preconceitos contra a população, os dirigentes nacionais teimam na fórmula civilizadora que lhes assegura os favores e o financiamento da comunidade internacional. Constitutivamente e por opção deliberada, a elite (ainda!) é latina. Porém, por querer liderar com um autoritarismo e uma condescendência de missionários, debate-se em meio aos conflitos que não podem ser solucionados sem pôr em risco sua preeminência.

Durante o século XIX, as negociações entre os notáveis regionais apoiados por seus exércitos semiprivados produzem soluções mais duradouras que as intervenções estrangeiras que, no início do século XX, aumentam a instabilidade política. Nesse século, os Estados Unidos impõem sua hegemonia no continente e não podem simplesmente assegurar seus interesses geopolíticos sem privilegiar uma facção da elite sobre a outra, mas podem elegantemente se oferecer como modelo, promotor e exemplo de democracia. Cada uma das facções da elite haitiana negocia separadamente com a comunidade internacional e lhe facilita a tarefa de dividir para reinar.

Tudo indica que o povo haitiano bem que poderia aceitar, como os demais caribenhos, o papel civilizador do Ocidente se existissem vantagens materiais correspondentes. Porém, nenhuma fórmula econômica pode integrar o Haiti ou uma proporção, ao menos significativa, de seus nacionais no chamado mundo moderno e nenhuma fórmula de etnocídio, sem um incremento significativo da qualidade de vida, pode ser atrativa. Contemporaneamente, a única maneira de acabar a pobreza no Haiti consiste em inundá-lo com dádivas em aumento exponen-

${ }^{50}$ Ver nota 14. 
cial. Sendo improvável esse curso da ação, uma conclusão se impõe: a solidão do Haiti o define e é inevitável.

Em Saint-Domingue, "viver livre ou morrer" haveria de significar morrer. No Haiti contemporâneo, parece que a opção de viver livre está se cancelando. As elites não podem resolver a crise contemporânea, se ainda não resolveram, apesar dos dois séculos que acabam de comemorar: 1) os vários conflitos que oporiam os habitantes de Saint-Domingue à França e à comunidade internacional; 2) os conflitos que oporiam os libertos aos "trabalhadores africanos" e 3) os que oporiam os libertos antigos aos de primeira geração. Convém assumir deliberadamente essas divergências e levar em consideração que cada grupo não pode fazer nada, além de obedecer a sua própria lógica. Quando essas velhas feridas se confrontarem, talvez possamos ajudar a cicatrizá-las e contribuir no processo de construção de um mundo no qual outros mundos são possíveis.

\section{Referências}

ARDOUIN, Beaubrun. Etudes sur l'Histoire d'Haïti, Paris: Dézobry et E. Magdeleine, 1853.

BARTHÉLÉMY, Gérard. Dans la splendeur d'un apres midi d'histoire. Port-au-Prince: Deschamps, 1996.

BARTHÉLÉMY, Gérard. Le pays en dehors: essai sur l'univers rural haïtien. Port-au-Prince: Henri Deschamps et CIDHICA, 1989.

BECKLES, Hilary. Black rebellion in Barbad: the struggle against slavery, 1627-1838. Barbados: Antilles, 1984.

BENOT, Yves. La modernité de l'esclavage: essai sur la servitude au cœur du capitalisme. Paris: La Découverte, 2003.

DEIVE, Carlos Esteban. Los guerrilleros negros. Santo Domingo: Fundación Cultural Dominicana, 1997.

DUBOIS, Laurent. Avengers of the New World: The story of the haitian revolution. Cambridge, Mass: Harvard University Press, 2004.

DUBOIS, Laurent. The promise of Revolution: SaintDomingue and the Struggle for Autonomy in Guadeloupe, 1789-1802. In: GEGGUS, David (Ed.). The impact of the Haitian Revolution in the Atlantic World. Columbia, South Carolina: University of South Carolina Press, 2001.
DUVALIER, François. Le problème des classes sociales à travers l'Histoire d'Haíti. Éléments d'une Doctrine, 3. ed. Port-au-Prince, 1968.

FOUCHARD, Jean. Les marrons de la liberté. Paris: Editions de l'École, 1972.

GAILLARD-POURCHET, Gusti Klara. Haïti, 18041987: Vers un État-Nation souverain et démocratique?. Revue de la société d'histoire et de géographie, année 78, n. 216, oct. 2003-mars 2004.

HECTOR, Michel; CASIMIR, Jean. Le long 19ème siècle haïtien. Revue de la Société Haïtienne d'Histoire et de Géographie. Port-au-Prince: Éditions des Antilles. Année 78, n. 216, oct. 2003-mars 2004.

HOFFMAN, Léon-François. Haïti, Couleurs, croyances, créole. Port-au-Prince: Henri Deschamps et les Éditions du CIDIHCA, 1990.

HURBON, Laënnec (Éd). L'insurrection des esclaves de Saint-Domingue (22-23 août 1791). Paris: Karthala, 2000.

JANVIER, Louis Joseph. Les constitutions d'Haïti, 18011885. Paris: C. Marpon et E. Flammarion, 1886.

KRIEGEL, Blandine. L'État et les esclaves: Réflexion pour l'histoire des états. Paris: Payot \& Rivages, 2003.

MADIOU, Thomas. Histoire d'Haiti, Tome I, 1492-1799. Port-au-Prince: Henri Deschamps, 1989.

MANIGAT, Leslie François. Les deux cents ans d'histoire du peuple haïtien, 1804-2004. In: RÉFLEXIONS à l'heure $d u$ bilan d'une évolution bi-centenaire. Port-au-Prince: Lorquet, 2002.

MEILlASOUX, Claude. Parents et étrangers. In: MEILlASOUX, Claude. Anthropologie de l'esclavage. Paris : Quadrige/Presses Universitaires de France, 1998.

NICHOLLS, David. Haiti in Caribbean Context: ethnicity, economy and revolt. London: The Macmillan Press, 1985.

PEZZULLO, Ralph. Plunging into Haiti: Clinton, Aristide, and the defeat of diplomacy. Jackson: University Press of Mississippi, 2006.

PRICE-MARS, Jean. La vocation de lélite. Port-au-Prince, Haiti: E. Chenet, 1919.

RAMSEY, Kate. Prohibition, Persecution, Performance, Anthropology and the Penalization of vodou in Mid-20thCentury. Paris: Gradhiva, 2005. 
SAINT-AMAND, J. Le code rural d'Haïti, avec commentaires et formulaires. Port-au-Prince: Edmond Chenet, 1921.

SAINT-LOUIS, Vertus. Les termes de citoyen et Africain pendant la revolution de Saint-Domingue. In: HURNON, Laenec (ed.). L'Insurrection des esclaves de Saint-Domingue (22-23 août 1791). Paris: Khartala, 2000.
SALA-MOLINS, Louis. Le code noir ou le calvaire de Canaan. 2. ed. Paris: Quadrige, 2003.

WOLFE, Marshall. Elusive Development, United Nations Research Institute for Social Development and Economic Commission for Latin America, 1981. 